\title{
GINS, a novel multiprotein complex required for chromosomal DNA replication in budding yeast
}

\author{
Yuko Takayama, ${ }^{1,2,4,5}$ Yoichiro Kamimura, ${ }^{1,2,4}$ Mariko Okawa, ${ }^{3}$ Sachiko Muramatsu, ${ }^{1}$ Akio Sugino, ${ }^{3}$ \\ and Hiroyuki Araki ${ }^{1,2,6}$ \\ ${ }^{1}$ Division of Microbial Genetics, National Institute of Genetics, Mishima, Shizuoka 411-8540, Japan; ${ }^{2}$ The Graduate \\ University for Advanced Studies, Mishima, Shizuoka 411-8540, Japan; ${ }^{3}$ Laboratories for Biomolecular Networks, Graduate \\ School for Frontier Biosciences, Osaka University, Osaka 565-0871, Japan
}

Eukaryotic chromosomal DNA replication requires a two-step assembly of replication proteins on origins; formation of the prereplicative complex (pre-RC) in late $M$ and G1 phases of the cell cycle, and assembly of other replication proteins in S phase to load DNA polymerases to initiate DNA synthesis. In budding yeast, assembly of Dpb11 and the Sld3-Cdc45 complex on the pre-RC at origins is required for loading DNA polymerases. Here we describe a novel replication complex, GINS (Go, Ichi, Nii, and San; five, one, two, and three in Japanese), in budding yeast, consisting of Sld5, Psf1 (partner of $\underline{\text { Sld }}$ five $\underline{1}$ ), Psf 2 , and Psf3 proteins, all of which are highly conserved in eukaryotic cells. Since the conditional mutations of Sld5 and Psf1 confer defect of DNA replication under nonpermissive conditions, GINS is suggested to function for chromosomal DNA replication. Consistently, in S phase, GINS associates first with replication origins and then with neighboring sequences. Without GINS, neither Dpb11 nor Cdc45 associates properly with chromatin DNA. Conversely, without Dpb11 or Sld3, GINS does not associate with origins. Moreover, genetic and two-hybrid interactions suggest that GINS interacts with Sld3 and Dpb11. Therefore, Dpb11, Sld3, Cdc45, and GINS assemble in a mutually dependent manner on replication origins to initiate DNA synthesis.

[Keywords: DNA replication; replication protein; Dpb11; Sld3; Sld5]

Supplemental material is available at http://www.genesdev.org.

Received December 9, 2002; revised version accepted March 17, 2003.

The integrity of chromosomal DNA requires complete and precise DNA replication. To achieve this, eukaryotic DNA replication is highly governed by an ordered series of steps in which multiple macromolecular protein complexes are assembled and disassembled at replication origins. In Saccharomyces cerevisiae, chromosomal DNA replication is initiated in a restricted region, the autonomously replicating sequence (ARS; for review, see Campbell and Newlon 1991). The six-subunit origin recognition complex (Orc) binds to origins throughout the cell cycle (Aparicio et al. 1997; Tanaka et al. 1997). Inactivation of cyclin-dependent kinases (Cdks) from late $M$ phase to G1 phase stimulates the recruitment of the minichromosome maintenance ( $\mathrm{Mcm})$ complex (Mcm27) onto origins by Cdc6 and Cdt1 to form the prereplicative complex (pre-RC). The Sld3-Cdc45 complex also as-

\footnotetext{
${ }^{4}$ These authors contributed equally to this work.

${ }^{5}$ Present address: Institute of Life Science, Kurume University, Kurume 839-0861, Japan.

${ }^{6}$ Corresponding author.

E-MAIL hiaraki@lab.nig.ac.jp; FAX 81-55-981-6762.

Article and publication are at http://www.genesdev.org/cgi/doi/10.1101/ gad.1065903.
}

sociates with origins, and its association depends on the pre-RC (Aparicio et al. 1999; Zou and Stillman 2000; Kamimura et al. 2001). At the onset of $S$ phase, when $\mathrm{Cdk}$ and $\mathrm{Cdc} 7$ protein kinases are activated, replication origins are unwound and the three DNA polymerases, Pols $\alpha, \delta$, and $\varepsilon$, essential for chromosomal DNA replication, are recruited to origins to initiate DNA synthesis.

For DNA polymerases to associate with origins, the Dpb11 protein is required. Dpb11 has four copies of the

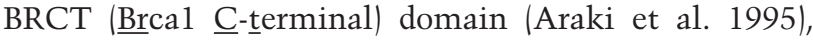
which is important for protein-protein interactions (Bork et al. 1997; Callebaut and Mornon 1997; Zhang et al. 1998), and forms a complex with Pol $\varepsilon$ and Sld2. The Dpb11-Pol $\varepsilon$ complex is detected predominantly in $S$ phase using cross-linking reagent, and its formation depends on $\mathrm{Dpb} 2$, the second largest subunit of Pol $\varepsilon$. Because the associations between origins and Dpb11 and Pol $\varepsilon$ are mutually dependent, the latter seems to associate with origins as a complex. Furthermore, the association of Dpb11 with origins is required for the loading of Pol $\alpha$ (Masumoto et al. 2000). The Sld2-Dpb11 complex is essential for DNA replication (Kamimura et al. 
1998). In contrast to the Dpb11-Pol $\varepsilon$ complex, the Sld2Dpb11 complex is detected without cross-linking. We recently showed that Sld2 is phosphorylated by S-Cdk and that this phosphorylation is necessary for the formation of the Sld2-Dpb11 complex, and we suggested that the association of polymerase with replication origins is regulated positively by S-Cdk activity via the complex formed between Sld2 and Dpb11 (Masumoto et al. 2002).

In higher eukaryotes, the same scenario seems to take place at replication origins, with some exceptions. Orc1 disappears in G2 and M phases, and counterparts of the three proteins, Dpb11, Sld2, and Sld3, have not been identified on the basis of amino acid sequence homologies, whereas homologs have been identified in fission yeast. Nonetheless, Drosophila Mus101 (Yamamoto et al. 2000) and human TopBP1 (Mäkiniemi et al. 2001), which have seven and eight BRCT domains, respectively, and play roles in DNA replication and repair, are thought to be functional homologs of Dpb11. Therefore, we expect that functional homologs of Sld2 and Sld3 will be found in higher eukaryotes in the near future.

We have isolated sld1-6 (synthetic lethality with dpb11-1) mutations (Kamimura et al. 1998) to clarify the function of Dpb11. Sld1 is identical to Dpb3, the third largest subunit of Pol $\varepsilon$ (Araki et al. 1991). Sld4 is identical to Cdc45, which is required for the initiation of and elongation of chromosomal DNA replication (Hopwood and Dalton 1996; Zou et al. 1997; Tercero et al. 2000). Sld6 is identical to Rad53, which is required for cellcycle checkpoints (Stern et al. 1991). The Sld2 and Sld3 proteins function for chromosomal DNA replication, and their roles in replication have been described above. In the present study, we analyzed one of the $S L D$ genes isolated by screening, SLD5, and we demonstrate that the Sld5 protein is a component of GINS (Go, Ichi, Nii,

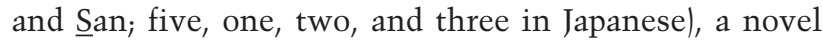
protein complex. GINS consists of Psf1 (partner of Sld five 1), Psf2, Psf3, and Sld5, all of which are well conserved in eukaryotic cells, and is essential for chromosomal DNA replication. We also show that GINS associates with replication origins and then with neighboring fragments during the S phase. Finally, from genetic and two-hybrid interactions between the genes, we infer that GINS mediates between the Sld3-Cdc45 and Dpb11-Pol $\varepsilon$ complexes to facilitate proper association between origins and DNA polymerases at the initiation of DNA replication.

\section{Results}

Isolation of a novel protein complex

We previously described cloning the SLD5 gene (Kamimura et al. 1998). The SLD5 gene corresponds to the YDR489w open reading frame (ORF; Saccharomyces Genome Database) and encodes a $34-\mathrm{kD}$ protein essential for cell growth (Winzeler et al. 1999; M. Okawa, Y. Kamimura, A. Sugino, and H. Araki, unpubl.). Because we detected no obvious phenotype in the original sld5-1 mu- tation itself (Kamimura et al. 1998), four thermosensitive mutations (sld5-2, sld5-8, sld5-12, and sld5-13) were isolated using the plasmid-shuffling method (see Materials and Methods), and their mutation sites were determined (Fig. 1A).

To identify factors interacting with Sld5, we screened for a multicopy suppressor of the sld5-12 mutation and isolated PSF1 (Fig. 2A). The PSF1 gene corresponds to the YDR013w ORF, which encodes a $24-\mathrm{kD}$ protein and is essential for cell growth (Dardalhon et al. 2000; M. Okawa, Y. Kamimura, A. Sugino, and H. Araki, unpubl.). A psf1-1 thermosensitive mutant was isolated using the plasmid-shuffling method (see Materials and Methods). We then screened for a multicopy suppressor of the psf1-1 mutation and found a new gene, PSF3 (Fig. 2A). PSF3 corresponds to the YOL146w ORF and is also essential for cell growth. Although we did not isolate it during screening, high-copy SLD5 weakly suppressed the psf1-1 mutation. Furthermore, we identified Psf2 by coimmunoprecipitation with Psf1 (see below), and the PSF2 gene on a high-copy plasmid also suppressed the sld5-12 mutation (Fig. 2A). These genetic interactions between SLD5, PSF1, PSF2, and PSF3 suggest that their products form a complex in the cell.

Therefore, we attempted to purify the complex containing Sld5 and Psf proteins. To this end, we substituted 6FLAG-PSF1 for the wild-type PSF1 gene. The resultant strain grew as well as the wild-type cells, suggesting that the 6Flag tag does not interfere with the biological function of the Psf1 protein. An anti-Flag immunoprecipitation was performed on both wild-type and 6Flag-Psf1 cell extracts, and the eluates with $3 \times$ Flag peptide from immunoprecipitates were separated by sodium dodecyl sulfate-polyacrylamide gel electrophoresis (SDS-PAGE; Fig. 3A, lanes 1,2). After the gel was stained with silver, we identified four discrete protein bands (p35, p30, p25, and p22) present specifically in the 6Flag-Psf1 immunoprecipitate (Fig. 3A, lane 2). We analyzed the same eluates by 2-D gel electrophoresis and identified four discrete spots corresponding to these bands (data not shown). These results suggest that anti-Flag antibody precipitated four distinct protein species. To ascertain whether these proteins occur in the same complex, we subjected the eluates to gel filtration column chromatography and demonstrated that the four proteins coeluted from the column in almost the same fraction as aldolase (158 kD; Fig. 3B). This result strongly suggests that the four proteins form a complex in the cell.

To prove that Sld5 and Psf3 occur in the complex, they were tagged in 6Flag-Psf1 cells with glutathione $S$-transferase (GST) at the $\mathrm{N}$ terminus (Sld5) or with 3-hemagglutinin (3HA) at the $\mathrm{C}$ terminus (Psf3), and cellular proteins were immunoprecipitated with 6Flag-Psf1. The Psf3 fused with the HA tag shifted from a $22-\mathrm{kD}$ band (Fig. 3A, lane 3) to a $27-\mathrm{kD}$ band, which was detected by Western blotting using anti-HA antibody (data not shown). Therefore, we concluded that $\mathrm{p} 22$ is encoded by PSF3. Cells in which GST-SLD5 was substituted for SLD5 grew slowly, and the amount of immunoprecipitate was reduced. Although the intensity of the discrete 
A SLD5
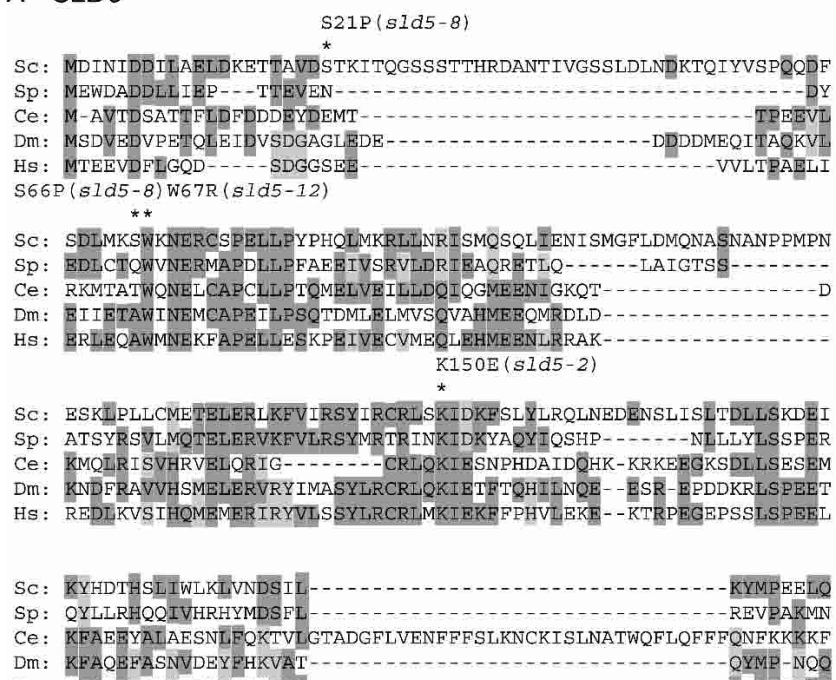

HS: AFAREFMANTESYLKNVAI -

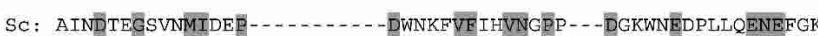
Sp: KLDDKVVGNLSMVASP -.......--DMETAVVFVVNESV - - EENFR--.-VSENEY Ce: ONSOKKTFFFKISKKKKKFPKNSOESS EFMPAALKKMPVPRGDHDDVMVYAKVTSDDVGNV

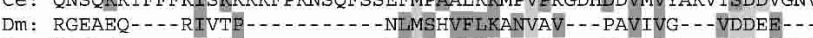

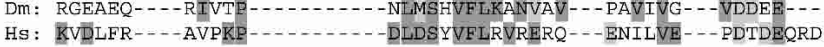
L293P (sIdis-13)

SC: PCYTVTI PDLKEEVELTIGS IYVMRYEVTRDTLRDDKVE

Sp: - -

Ce: AIPDWQDLNGEVILEMEPESCHLIPE ESVHQIVEDGNIQLM
$\mathrm{Dm}$ :

Hs : YV-........-_DLEKGSOHLIRYKT LAPLVASGAVOLI

\section{PSF2}

SC: - -MSLPAHLLQTFSPEEIQFIVENEPTKIFTRTTTROKIRGDDRGTGNHTRWQITITTDDK SP: - - MALPRELEISFSPEEMEFLAGNE Y NIVIPSETMDQLP - . - . - . - . - - LVS - - - A $\mathrm{Sp}:-$ MALPRELEISFSPEEMEELAENY $\mathrm{Ce}$ : -

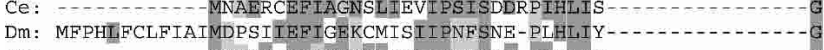

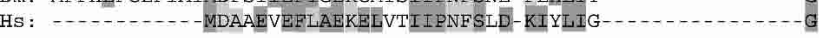

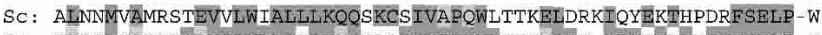
Sp: TTPIMKPPKKCRVPL WT, AI ETKRQNLARTVPPEWMEIGKLFN-TRDDETENETPSRT P-F Ce: DIGPFEAGVPCRIPVWTAILMKRKHNCKVVAPQWMDVDBL KK - ILTSETESOGLAKL -D Dm: PVGPERAGFPVFVPLWMATHLRKQQKCRIVPPEWMDMDILAE-IKEEEKR SKFFTKMECE Hs: DLGPFNPGLPVEVPLWTAINLKQRQKCRLLPPEWMDVEKLEK-MRDHERKEETETPMISP

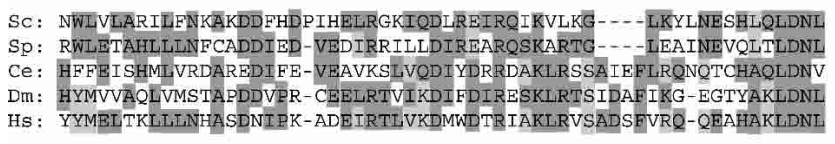
Hs: YYMELTKLLINHASDNIEK-ADEIRTLVKDMWDTRIAKLRVSADSFVRD̈-QEAHAKLDNI

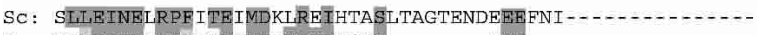

$\mathrm{Sp}$ : GAMEINEIRPIFREVMDRMRKIVQVS- - . - QEEE

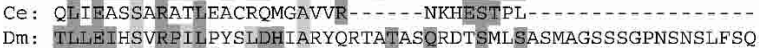

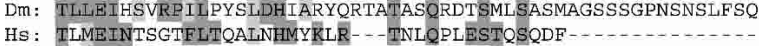

\section{B PSF1}

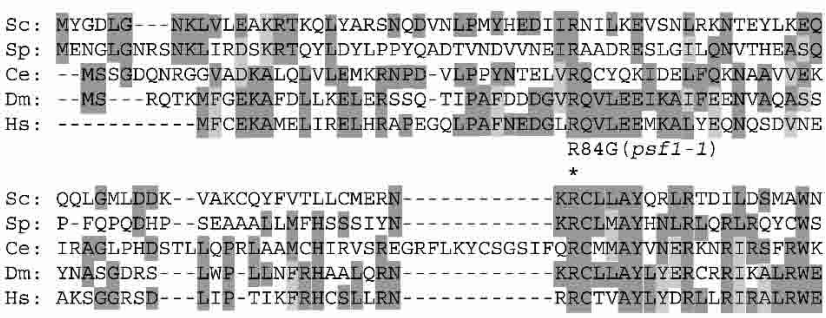

SC: NNGLLDESSITESQODTTNNLSHOEE Sp: G-GKRMESCLDTS -...--LSTYERDYLTRYSELLAAYK-GAWSELDLTGSLVVPKNLEI

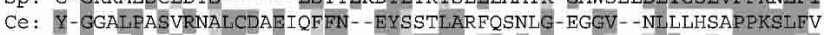
$\mathrm{Dm}$ : F- GPIIPGDIKQALCEPEVTFFN--NYSKSLAYYMCSAGYNOGLPIDLTNNIRPPRSLYI

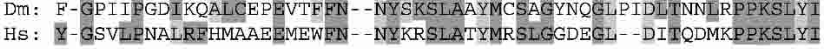

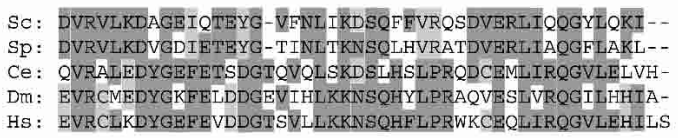

\section{PSF3}

SC: MIYPSLRVLRDKCRRVVKIAMELMPTLELVLY YYNRRASIERMIGYYDIDDVIIADGTEFPC Sp:

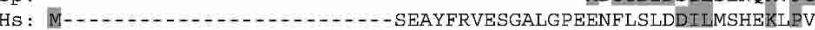

SC: KFOYDIPGLGYL------ENNPGRPITKNTKISSLPLWI ARILATVGGDEALVDEEPVPFV

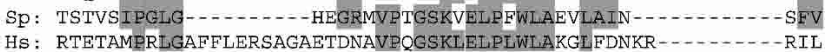
SC: ELLPREDMFSTKVMNAIKTTDPVALDLHSINSHFFSLAIKWEMLFSEKEIANVVSELLLQRA Sp: SIHMPAPFSSVVRAALKANPNSVS IRDITTHYYHFAEKML.HL ISDDSLVQISLNTLRSRA Hs : SVELPKIYQEGWRTVF SADPNVVDLHKMGPHEYGFGSOLIHFDSP - ENADISOSLLQTEI

SC: QELNHHASSLSIDENADSTGKNSANTN IATST TLLKLEEMEKETYKKSHESYKФTKRWMMF SP: MLIADASLNPQGALQQNSQ -........... TEGLDDFEKHILRVSHNAHRSLINWQN Hs: GRFRRIMDSSQNAYNEDTS -......... -ALVARIDEMERGLFQTGQKGLNDFQCWEK

Sc: $\mathrm{KK}-\ldots$ Sp: STS

Figure 1. Sld5, Psf1, Psf2, and Psf3 are conserved among eukaryotes. Amino acid sequence alignment of S. cerevisiae Sld5 (Sc; A), Psf1 $(\mathrm{Sc} ; B)$, Psf2 $(\mathrm{Sc} ; C)$, and Psf3 (Sc; D) and their homologs from S. pombe (Sp), Caenorhabditis elegans (Ce), Drosophila melanogaster $(\mathrm{Dm})$, Homo sapiens (Hs). Amino acids conserved in all aligned sequences are shown with dark shadow, and those conserved in at least two sequences but not all are shown with light shadow. sld5 mutation sites and psf1-1 mutation sites are shown by asterisks with the amino acid changes in $A$ and B. sld5-2, sld5-12, and sld5-13 mutations were identified at positions 448 (A to G), 199 (T to C), and 878 ( $\mathrm{T}$ to $\mathrm{C}$ ) in the nucleotide sequence (nucleotide 1 is A of the first ATG of the ORF). These mutations change the amino acids of Sld5 from conserved lysine, tryptophan, and leucine to glutamic acid, arginine, and proline, respectively. The sld5-8 allele has two alterations occurring at nucleotides 61 ( $\mathrm{T}$ to $\mathrm{C}$ ) and 196 ( $\mathrm{T}$ to $\mathrm{C}$ ), which both result in the replacement of serine with proline $(A)$. However, we do not know whether two-site mutations are required for temperature sensitivity. The psf1-1 mutation site was identified at position 250 (A to G) in the nucleotide sequence, which changes an arginine to glycine $(B)$. 
Figure 2. The genetic and two-hybrid interactions between Dpb2, Dpb11, Sld2, Sld3, Cdc45, Psf1, Psf2, and Psf3. (A) Suppression of thermosensitive growth of sld512 and psf1-1. YYK38 (sld5-12) cells and YYT1 (psf1-1) cells carrying different plasmids were streaked onto YPDA plates and incubated at the indicated temperatures. The genes in the left half of the diagram were cloned into YCplac22 (the low-copy vector), and the genes in the right half were cloned into YEp195 (the high-copy vector). (B) Two-hybrid interactions between Psf1 and Dpb2, Dpb11, Sld3, or Sld5. "Vector" and "Psf1" in pBTM116 denote plasmids that express LexABD and LexABD-Psf1, respectively. V, DPB2, DPB11, SLD3, and SLD5 in pACT2 denote plasmids that express Gal4AD and Gal4AD fusion with Dpb2, Dpb11, Sld3, and Sld5, respectively. Transformants of L40 each carrying a pair of plasmids were assayed for $\beta$-galactosidase activity by colony color with X-Gal. (C) Summary of genetic and two-hybrid interactions among Dpb2, Dpb11, Sld2, Sld3, Cdc45, Psf1, Psf2, and Psf3. The blue line shows multicopy suppression; the red line shows a positive signal in the two-hybrid assay.
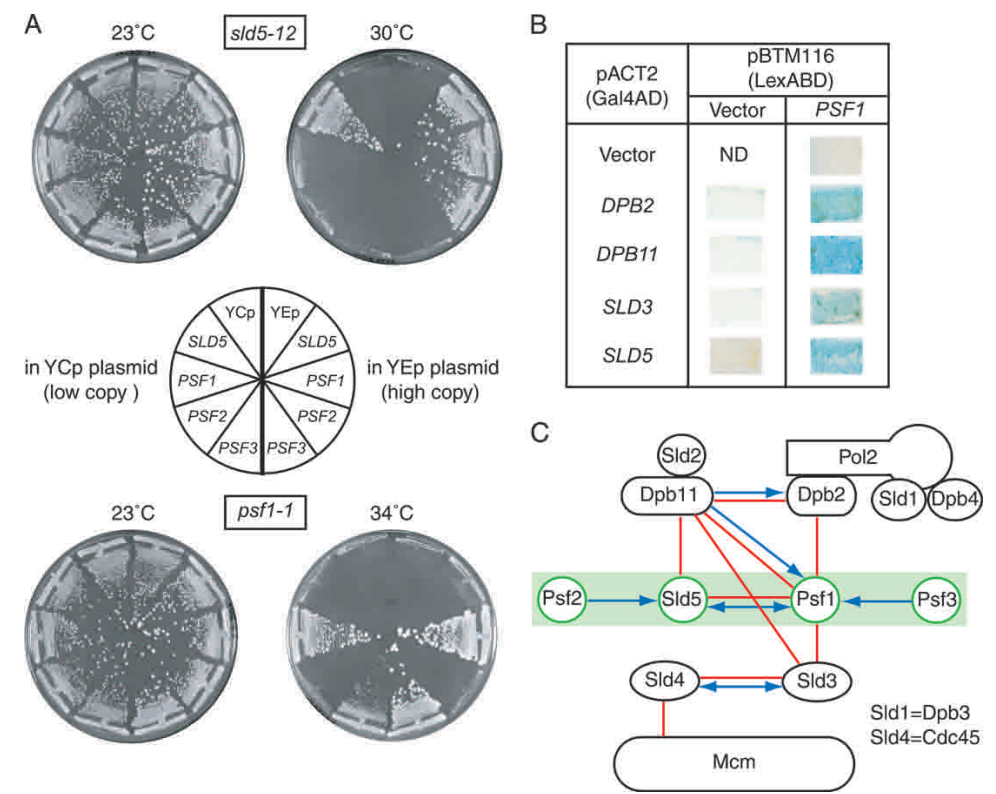

bands was weak, we observed a novel $60-\mathrm{kD}$ band in the immunoprecipitates (Fig. 3A, lane 7). Moreover, Western blots probed with anti-Sld5 antibodies reacted with p35 from cells expressing SLD5 but not from cells expressing GST-SLD5, whereas both anti-Sld5 and anti-GST antibodies reacted with p60 (Fig. 3A, lanes 8-11). This result strongly suggests that p35 is encoded by SLD5. Because a weak signal was observed in the same position as p35 in wild-type cells (Fig. 3A, lane 1), the p35 signal remaining in cells expressing GST-SLD5 might constitute nonspecific background.

The other two discrete protein bands were subjected to peptide mass fingerprinting analysis, and p30 was identified as Psf1. p25 was the product of a new essential gene, PSF2, encoded by the YJL072c ORF. Consistent with this finding, the p30 band was detected using not only anti-Flag but also anti-Psf1 antibodies (data not shown). Therefore, we concluded that p30 is 6Flag-Psf1. Replacement of Psf2 by Psf2 tagged with 13-Myc at its C terminus in 6Flag-Psf1 cells shifted the p25 band to a more slowly migrating band (Fig. 3A, lane 4). This shifted band was detected using anti-myc antibody (data not shown), indicating that PSF2 encodes p25. Together with their genetic interactions, these results strongly suggest that Sld5, Psf1, Psf2, and Psf3 form a complex. We named this complex GINS. The abundance and composition of GINS were constantly maintained during the cell cycle (data not shown).

The amino acid sequences of Sld5, Psf1, Psf2, and Psf3 are well conserved among eukaryotic organisms, and some of their mutations occur at highly conserved amino acid residues (Fig. 1), suggesting that a similar complex exists in all eukaryotic cells. However, the Nterminal portion of the predicted amino acid sequence of Psf3 is absent in its homologs in other organisms. Moreover, the apparent molecular mass of Psf3 on SDS-PAGE is smaller than the predicted molecular mass (Fig. 3).
Therefore, we surmise that the fourth ATG in the predicted YOL146w ORF is used for translation.

\section{Genetic interactions between SLD5, PSF1, and DPB11}

Because sld5-1 was isolated as a synthetically lethal mutation with $d p b 11-1$ (Kamimura et al. 1998), we examined the synthetic lethality between psf1-1, sld5-12, and dpb11-1. We crossed all possible combinations of these mutants. The resultant diploids were allowed to sporulate and were then dissected. Of the 20 tetrads obtained from each diploid, no spore clones carrying two of these mutations were isolated. These results indicate that any pair of psf1-1, sld5-12, and $d p b 11-1$ is lethal, even at permissive temperatures, and suggest that both Psf1 and Sld5 interact with Dpb11. This is further supported by the finding that high-copy DPB11 suppressed a psf1-1 mutation (data not shown). We also found that SLD5 on a high-copy plasmid weakly suppressed the growth defect of $d p b 11$ mutant cells at the restrictive temperature. Moreover, the growth defect of $d p b 11$ mutant cells was restored better by the simultaneous introduction of highcopy SLD5, PSF1, and PSF3 than by SLD5 alone (data not shown).

To confirm these genetic results, we examined whether Psf1 interacts with Dpb2, Dpb11, Sld3, and Sld5 in a two-hybrid assay. As shown in Figure 2B, Psf1 interacted with Dpb2, Dpb11, Sld3, and Sld5. These genetic and two-hybrid data are summarized in Figure 2C and will be discussed below.

\section{GINS is required for essential function}

Although the SLD5, PSF1, PSF2, and PSF3 genes are all essential for cell growth, it was unclear whether the formation of GINS is essential for cell growth. If its forma- 


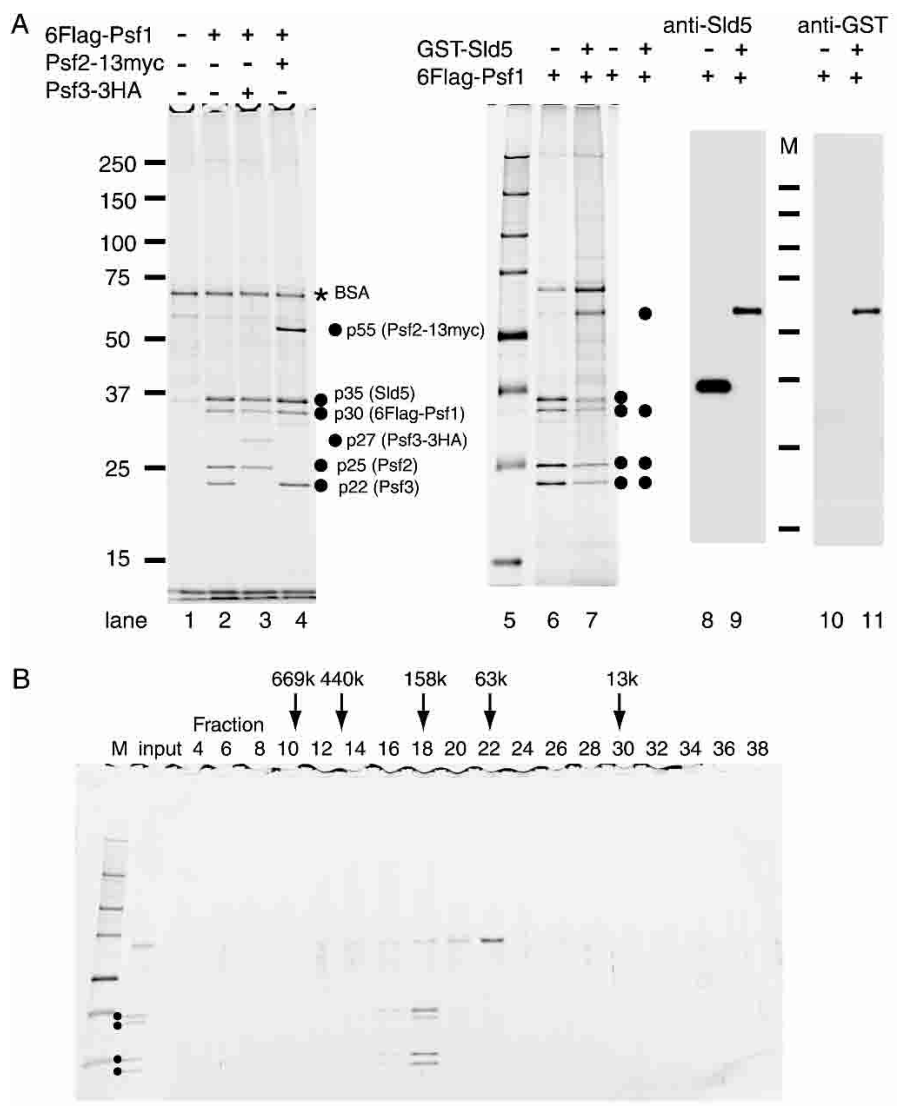

C

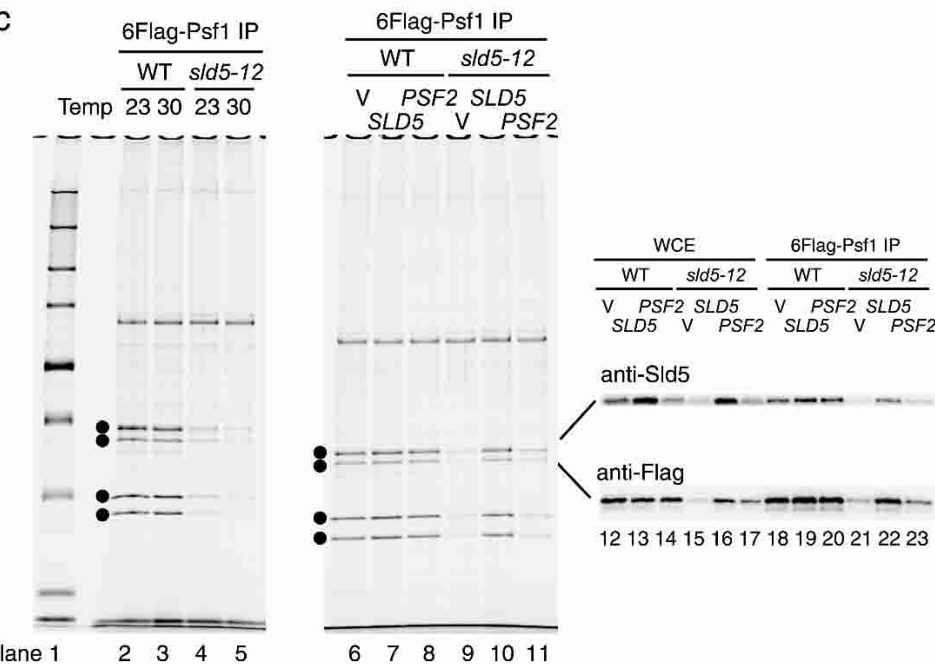

Figure 3. Sld5, Psf1, Psf2, and Psf3 form a complex. $(A)$ Protein extracts were prepared from cells of the indicated genotypes. +, an epitope-tagged gene; -, a wildtype allele. Anti-Flag immunoprecipitations were performed. The immunoprecipitated proteins were separated by $4 \%-20 \%$ SDS-PAGE and subsequently silverstained (left and center panels). In the right panel, immunoprecipitates from 6Flag-Psf1 or 6Flag-Psf1 GST-Sld5 cell extracts were probed with anti-Sld5 or anti-GST antibodies. (B) A gel filtration chromatography of 6Flag-Psf1 immunoprecipitates using Superdex 200 was performed as described in Materials and Methods. The proteins in each column fraction were identified by $5 \%-20 \%$ SDS-PAGE followed by silver staining. The first lane contains protein molecular-weight standards $(\mathrm{M})$, and the second lane contains the input sample. The Superdex 200 column was calibrated with tyroglobin (669 kD), ferritin (440 kD), aldolase (158 kD), BSA (63 kD), and RNase A (13 kD). (C) YYK46 (6FlagPsf1, WT) and YYK50 (6Flag-Psf1 in sld5-12) cells were cultured at $23^{\circ} \mathrm{C}$ to $1 \times 10^{7}$ cells $/ \mathrm{mL}$. Half of each culture was shifted to $30^{\circ} \mathrm{C}$ while the other half was maintained at $23^{\circ} \mathrm{C}$, and incubations were continued until cells reached $2 \times 10^{7}$ cells/mL (left panel). YEp195 (V), YEp195-SLD5 (SLD5), and YEp195-PSF2 (PSF2) plasmids were introduced into YYK46 (6Flag-Psf1; WT) and YYK50 (6Flag-Psf1 in sld5-12) cells. Cells carrying each plasmid were cultured at $23^{\circ} \mathrm{C}$ (center and right panels). Protein extracts were prepared from each culture, and anti-Flag immunoprecipitations were performed. The amount of GINS was estimated by staining with silver (left and center panels). In the right panel, whole cell extracts (WCE) and immunoprecipitates (IP) were immunoblotted with anti-Sld5 or anti-Flag antibodies. tion is essential for cell growth, GINS may be impaired by some mutations in these components, and might be restored by the overproduction of other components. This seems to be true, because high-copy SLD5 and PSF genes each suppressed the sld5-12 and psf1-1 mutations (Fig. 2A). Therefore, we examined the formation of GINS in the sld5-12 mutant. We did not examine the formation of GINS in psf1-1 cells, because we have not yet succeeded in constructing a tagged version of Psf1-1. We found that the amount of GINS recovered from sld5-12 cells was reduced to less than $1 / 5$ that from wild-type cells, even at the permissive temperature $\left(23^{\circ} \mathrm{C}\right.$; Fig. $3 \mathrm{C}$, lanes 4,5 ). As observed for the GST-Sld5 protein (Fig. 3A, lane 7), the amount of 6Flag-Psf1 in the precipitates was also reduced (to less than 1/5 that of wild-type cells; Fig. $3 \mathrm{C}$, lanes 9,21). Moreover, Western blotting revealed that the amounts of Psf1 and Sld5-12 proteins in the crude extract prepared from sld5-12 cells were also reduced (Fig. 3C, lane 15), as observed in the precipitates. These results suggest that the sld5-12 mutation impairs the formation of GINS and that uncomplexed Psf1 is degraded. Furthermore, sld5-12 cells carrying the high- 
Takayama et al.

copy PSF2 plasmid significantly restored the amount of GINS (Fig. 3C, lanes 11,23). As a control, the amount of GINS in wild-type cells carrying the vector, high-copy SLD5, and PSF2, was apparently constant (Fig. 3C, lanes $7,8,19,20)$. These results strongly suggest that GINS is required for cell growth and for chromosomal DNA replication (see below; Fig. 4).

\section{Sld5 and Psf1 are required for DNA replication}

The results described above suggest that Sld5 and Psf1 proteins function through GINS. Therefore, we examined the phenotypes of the sld 5 and psf1 thermosensitive mutants to clarify the biological function of GINS.

With a temperature shift up, the growth of all of the mutant sld5 and psf1-1 cells was arrested, and the cells displayed the dumbbell shape and a single nucleus (data not shown) that is the typical terminal morphology for mutants defective in DNA replication. We measured DNA synthesis in mutant cells at the restrictive temperature by FACS analysis. When cells were arrested in G1 phase with $\alpha$-factor and released at $36^{\circ} \mathrm{C}$, wild-type cells accumulated a $2 \mathrm{C}$ DNA content in $80 \mathrm{~min}$, then entered a second cell cycle. Cells carrying the sld5-12 mutation, which is the tightest allele of the sld5 mutations described above, reached a 2C DNA content gradually, entered the second cell cycle, and again gradually reached a 2C DNA content (Fig. 4A). These kinetics suggest that sld5-12 cells are partially defective in DNA replication. Defective DNA replication was more evident in the psf1-1 cells; their DNA content did not increase for $120 \mathrm{~min}$ and then reached 2C gradually (Fig. 4A). These are the typical kinetics of bulk DNA

Figure 4. sld5-12 and $p s f 1-1$ cells are defective in DNA replication. (A) FACS analysis of cells released from G1-phase arrest. Wild-type (WT), sld5-12, and psf1-1 cells were synchronized with $\alpha$-factor at $23^{\circ} \mathrm{C}$ and released from $\alpha$-factor at $36^{\circ} \mathrm{C}$. At the indicated times, aliquots were treated with propidium iodide and the DNA content was measured by FACScan. $1 \mathrm{C}$ and $2 \mathrm{C}$ indicate DNA contents of G1 and G2/M cells. $(B)$ Viability and cell morphology of sld5-12 and psf1-1 mutant cells. Portions of the same samples incubated at $36^{\circ} \mathrm{C}$ and described in $A$ were used to determine cell number and cell morphology. The cells were spread onto YPD plates to measure viability. $\mathbf{\square}$, viable cells; $\triangle$, cells without bud; $\square$, cells with small bud; $\bigcirc$, cells with large bud. $(C)$ N/N 2-D gel analysis of the chromosomal ARS1 locus in wild-type (WT), sld5-12, and psf1-1 cells. Cells were grown and harvested at $23^{\circ} \mathrm{C}$ or shifted to $37^{\circ} \mathrm{C}$ for $3 \mathrm{~h}$ prior to harvest. DNA was digested with NcoI and probed with ARS1-containing fragment. The diagrams besides photographs show the bubble to $\mathrm{Y}$ fork and Y fork arcs.

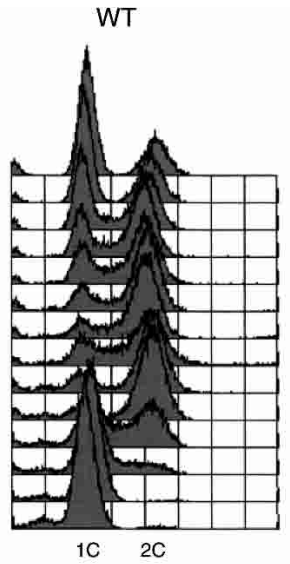

B

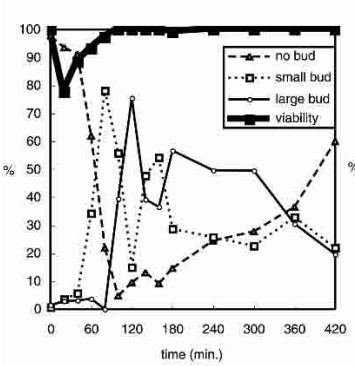

C

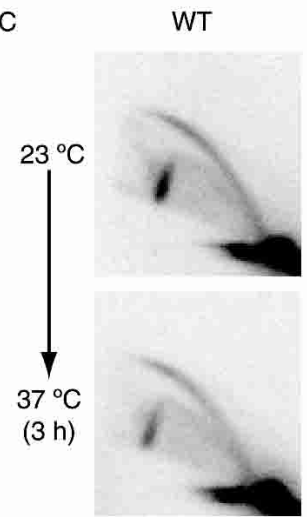

sld5-12

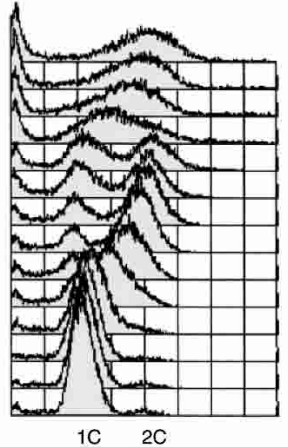

sld5-12

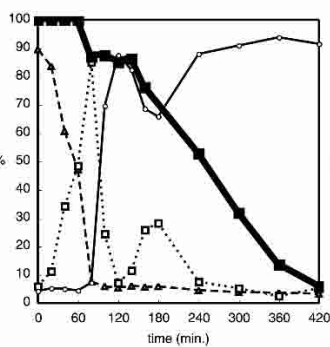

psf1-1

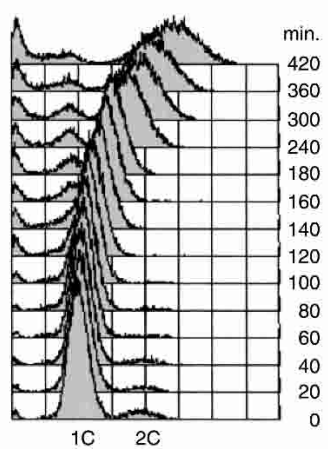

psf1-1

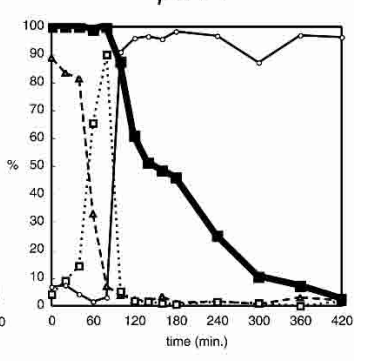

sld5-12

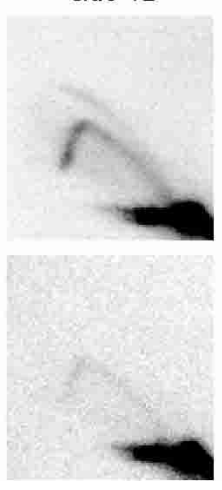

psf1-1

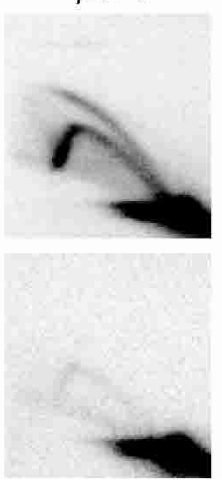

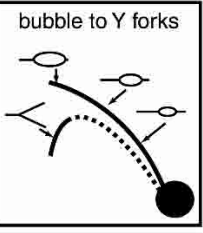

$Y$ forks

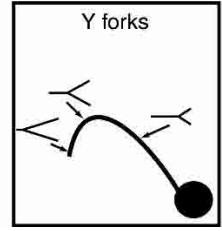


synthesis in mutants defective in the early step of DNA replication. On the other hand, when psf1-1 cells were arrested in $\mathrm{S}$ phase by hydroxyurea $(\mathrm{HU})$, and released at the restrictive temperature, they completed bulk DNA synthesis and entered the subsequent G1 phase, although the S-phase progression was substantially slowed relative to the wild-type control (data not shown).

Cells carrying orc2-1 (Bell et al. 1993), cdc45-1 (Zou et al. 1997), dpb11-1 (Kamimura et al. 1998), sld2-6 (Kamimura et al. 1998), and sld3-5 (Kamimura et al. 2001) are defective in the initiation of DNA replication and begin to lose viability immediately after the cells start budding at the restrictive temperature. To determine the point at which the cells start losing viability, the viability and cell morphology of synchronized cells were examined. Both sld5-12 and psf1-1 mutants started losing viability when cells began to bud (Fig. 4B), like mutants defective in the initiation of DNA replication.

To examine the DNA replication defect in sld5-12 and psf1-1 cells in detail, an active origin, ARS1, was analyzed by neutral/neutral two-dimensional gel (N/N 2-D gel; Brewer and Fangman 1987). Wild-type, sld5-12, and psf1-1 cells were grown to $\log$ phase at $23^{\circ} \mathrm{C}$ and shifted to $37^{\circ} \mathrm{C}$ for $3 \mathrm{~h}$ before harvest. At both $23^{\circ} \mathrm{C}$ and $37^{\circ} \mathrm{C}$, the wild-type cells gave a clear transition signal from bubble to fork arcs, indicating that replication initiates in the ARS1 region. In contrast, a complete fork in addition to a bubble arc was observed in sld5-12 and psf1-1 cells at $23^{\circ} \mathrm{C}$. Furthermore, the bubble arc signals were completely absent after temperature shift-up (Fig. 4C), suggesting the reduced frequency of initiation from ARS1.

The results described above, together with reduced associations between origins and the initiation proteins Cdc45 and Dpb11 in psf1-1 cells (see below), suggest that GINS participates in the initiation step of chromosomal DNA replication, although its involvement in the elongation step is ambiguous.

Cells lacking DNA replication proteins are arrested with a dumbbell shape in the mitotic cell cycle, as well as after germination from spores. After germination from spores, deletion mutants for each of SLD5, PSF1, PSF2, and PSF3 show the same morphologies, consistent with the formation of a complex by these gene products. However, the morphologies of those deletion mutants during germination are not typical for mutants defective in DNA replication; they appear as swelling spherical cells with small buds, split spheres, or lysed spheres, or dumbbell shapes, suggesting that these cells have a defect other than in DNA replication. In contrast to germinated cells, cells with a dumbbell shape that is typical for mutants defective in DNA replication accumulated in the mitotic cell cycle when the Psf1 plasmid was lost from YYK41 [Dpsf1 (YEp195-PSF1)] cells during shuffling (data not shown). Moreover, both psf1-1 and sld5-12 cells are arrested in the cell cycle with a dumbbell shape. Therefore, GINS seems to participate in biological processes other than DNA replication in germination from spores.

\section{Psf1 associates with origins in $S$ phase}

Because it had been suggested that Psf1 is required for the early step of DNA replication, we examined whether the Psf1 protein associates with the ARS region in vivo using a chromatin immunoprecipitation (ChIP) assay (Strahl-Bolsinger et al. 1997). We used PCR primers to amplify ARS1, ARS305, ARS501, and their neighboring regions (Fig. 5A; Tanaka and Nasmyth 1998). ARS1 and ARS305 fire early in S phase, and ARS501 fires late in S phase (Ferguson et al. 1991).

When we used cells carrying 6FLAG-PSF1 and antiFlag antibody, the ARS1 fragment was specifically amplified (Fig. 5B). However, no significant amplification of the ARS1 fragment was observed when we used cells without 6Flag-Psf1 (Fig. 5B), suggesting that the ChIP assay is Flag-tag-dependent. Moreover, the ARS1 fragment in cells bearing a mutation in ARS1 was not amplified, whereas the ARS305 fragment was observed (Fig. 5C). This result indicates that Psfl associates with functional origins.

Cells bearing 6FLAG-PSF1 were arrested in G1 phase with $\alpha$-factor and released at $16^{\circ} \mathrm{C}$ to slow replication fork movement. The ChIP assay revealed that Psf1 associates with early origins, ARS1 and ARS305, from 60 min after cells are released from $\alpha$-factor and with late origin, ARS501, from 75 min after release (Fig. 5E). Later, Psf1-association with non-ARS regions near the origins was also observed. Therefore, it is suggested that GINS associates with replication origins in S phase.

Sld3 is required for the association of Psf1 with origins

Sld3, which forms a complex with Cdc45, associates with early-firing origins from G1 phase (Kamimura et al. 2001). Therefore, we examined whether Sld3 is required for the association of Psf1 with origins. To slow the movement of replication fork and to prolong the period during which Psf1 might associate with origins, $\alpha$-factorarrested cells were released in medium containing 0.15 $\mathrm{M} \mathrm{HU}$ at $33^{\circ} \mathrm{C}$. In wild-type cells, 6Flag-Psf1 associated with ARS1 and ARS305 30 min after release from $\alpha$-factor (Fig. 5F). In contrast, no significant association was detected in sld3-5 cells at the restrictive temperature (Fig. 5F). These results suggest that Sld3 is required for the association of Psfl with origins.

\section{Cdc45 chromatin-binding step is impaired in psf1-1 cells}

The Cdc45 protein binds to chromatin in S phase. Because Psf1 associates with origins in S phase (Fig. 5), we examined whether the chromatin-binding of Cdc45 is affected by the psf1-1 mutation.

psf1-1 and wild-type cells were released from the G1 block and further incubated at $37^{\circ} \mathrm{C}$ to start the cell cycle. Budding occurred in these two strains with almost the same timing (date not shown). At 75 min, chromatinbound Cdc45 in psf1-1 cells was less abundant than in wild-type cells. Because it was reduced by DNase I treat- 
Takayama et al.

Figure 5. Association of Psf1 with ARS regions. (A) Genomic intervals near or at ARSs amplified by PCR primers. (B) Flag-Psf1 specifically associated with ARS1 in vivo. YYK9 (tag-) or YYT2 (6Flag-Psf1) cells were grown in YPAR at $23^{\circ} \mathrm{C}$. Immunoprecipitation (IP) was performed with anti-Flag antibody. PCR was performed on chromatin fragments isolated after IP or on those from the whole cell extracts (WCE). $(C)$ Flag-Psf1 specifically associated with functional ARS1. YYT2 (6FlagPsf1, ARS1-A; WT) or YYK51 (6Flag-Psf1, ARS1-A/860T $\rightarrow$ G; $\mathrm{m}$ ) cells were arrested in G1 phase by $\alpha$-factor at $23^{\circ} \mathrm{C}$ for $3 \mathrm{~h}$ and released in YPAR containing 0.15 $\mathrm{M} \mathrm{HU}$ at $23^{\circ} \mathrm{C}$. Cells were withdrawn after $30 \mathrm{~min}$. 6Flag-Psf1 was immunoprecipitated from each extract with an anti-Flag antibody. PCR was performed on immunoprecipitates derived from the same number of cells. (D) DNA content of synchronized cells used for the ChIP assay (E) was measured by FACS analysis. The percentage of budded cells is also shown. (E) Association of Flag-Psf1 with the ARS1, ARS305, or ARS501 regions. YYT2 cells were arrested in G1 phase with $\alpha$-factor and released in YPAD medium at $16^{\circ} \mathrm{C}$. Cells were withdrawn from the culture every 15 min and fixed with formaldehyde. Cell lysates were sonicated and used for immunoprecipitation. PCR was performed either on immunoprecipitates (IP) derived from the same number of cells at each time point or on the 0 -min chromatin fraction from whole cells extracts (WCE). (F) Association of Psf1 with the origin depends on Sld3. YYT2 (6Flag-Psf1; WT) and YYT3 (6Flag-Psf1; sld3-5) cells were arrested in G1 phase by $\alpha$-factor at $23^{\circ} \mathrm{C}$ for $3 \mathrm{~h}$ and released in YPAR containing $0.15 \mathrm{M} \mathrm{HU}$ at $33^{\circ} \mathrm{C}$. Cells were withdrawn from the culture every $30 \mathrm{~min}$. 6Flag-Psf1 was immunoprecipitated from each extract with an anti-Flag antibody. PCR was performed on immunoprecipitates derived from the same number of cells at each time point.

ment, Cdc45 in the pellet (P) fraction from the wild-type cells was associated with chromatin. In contrast, DNase I treatment did not reduce the amount of Cdc45 in the $\mathrm{P}$ fraction from psf1-1 cells (Fig. 6). Furthermore, we did not detect chromatin-bound Cdc45 in psf1-1 cells for 105 min after their release from $\alpha$-factor (data not shown). Therefore, Psf1 is required for the chromatin-binding of Cdc45. Because the association of Psf1 with origins depends on Sld3, which is essential for Cdc45 to function (Kamimura et al. 2001), the chromatin-binding of Cdc45 and the association of Psf1 with origins are mutually dependent.

\section{Associations of Psf1 and Dpb11 with origins are mutually dependent}

Dpb11, which is required for the association of DNA polymerases $\alpha$ and $\varepsilon$ with origins, associates with replication origins at the same time as Psf1 (Fig. 5E; Masumoto et al. 2000). Therefore, we examined whether the association of Psf1 with replication origins depends on
Dpb11. As shown in Figure 7A, the dpb11-26 mutation, which is a tighter allele isolated recently, reduced the specific signals for the association of 6Flag-Psf1 with ARS1 and ARS305 in the ChIP assay, indicating that Dpb11 is required for the proper association of Psf1 with origins.

Next, we examined whether Psf1 is required for the association of Dpb11 with replication origins. As shown in Figure 7B, specific signals indicating the association of Dpb11-9myc with ARS1 and ARS305 in psf1-1 cells were reduced significantly, implying that the association of Dpb11 with origins depends on Psf1. Therefore, we conclude that the associations of Psf1 and Dpb11 with origins are mutually dependent.

\section{Discussion}

In this study, we identified a novel protein complex, GINS, using genetic and biochemical methods. A similar complex has been identified in Xenopus egg extracts, in which anti-Sld5 antibodies depleted Psf1, Psf2, and Psf3, 

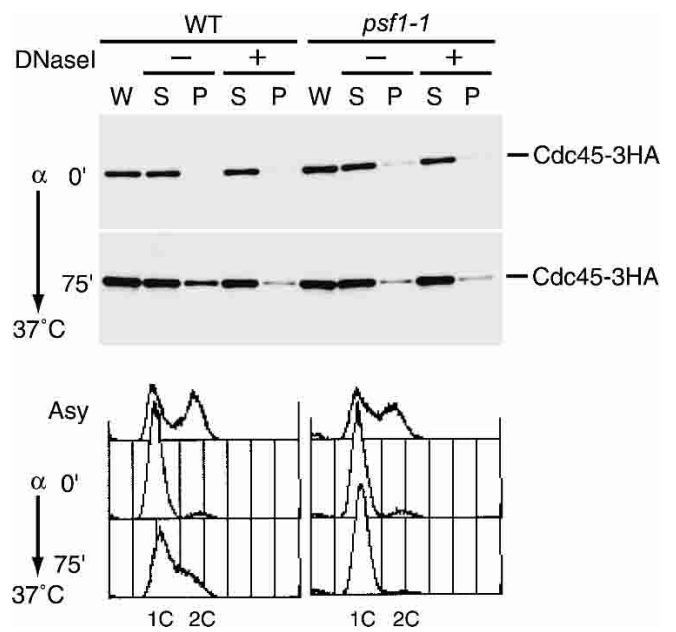

Figure 6. Cdc45 association with chromatin is reduced in the psf1-1 mutant cells. YYK20 (WT) and YYT4 (psf1-1) cells expressing Cdc45-3HA were synchronized in G1 phase by $\alpha$-factor and released at $37^{\circ} \mathrm{C}$. The cells were collected at the $\alpha$-factor block or $75 \mathrm{~min}$ after release. Chromatin-binding assay was performed as described (Kamimura et al. 2001). The proteins present in the different fractions of the chromatin purification were examined by immunoblotting of SDS-PAGE: W, whole cell extract; S, supernatant; P, pellet fraction. Extracts were incubated on ice either without $(-)$ or with $(+)$ DNase I. The bottom panel shows the DNA content of the samples used in the top panel.

suggesting that these proteins exist as a complex (Kubota et al. 2003). This is also true for yeast GINS, because almost all of Sld5, Psf2, and Psf3 are depleted with 6FlagPsf1 by anti-Flag antibody (Y. Kamimura and H. Araki, unpubl.). Further, we suggest that each protein functions through GINS, because high-copy PSF2 restored the growth and complex formation in sld5-12 cells (Figs. 2A, $3 \mathrm{C})$. We therefore discuss the biological roles of GINS inferred from the results obtained using sld5 and psf1 mutants.

\section{Assembly of replication proteins at replication origins}

To initiate DNA replication, many replication proteins assemble on replication origins (for review, see Bell and Dutta 2002; Nishitani and Lygerou 2002). In S. cerevisiae, the pre-RC is formed on replication origins from late $M$ phase to $\mathrm{G} 1$ phase. The Sld3-Cdc45 complex also associates with origins, and its association depends on the pre-RC. When S-Cdk and Cdc7 protein kinases are activated at the G1-S-phase boundary, DNA polymerases are recruited to origins to initiate DNA synthesis, and this step requires the function of Dpb11. Dpb11 forms a complex with both Sld2 and $\mathrm{Pol} \varepsilon$, and associates with origins, which is required for further associations between Pol $\alpha$-primase and origins (Masumoto et al. 2000). In the present study, we showed that Psf1 interacts with Dpb11, Dpb2, and Sld3, using a two-hybrid assay. It is therefore conceivable that GINS mediates the interaction between the Cdc45-Sld3 and Dpb11-Pol $\varepsilon$ complexes and thus promotes the association of the DNA polymerases with origins.

Interestingly, Dpb11 and Psf1 associate with origins interdependently (Fig. 7). This result does not support the idea that Psf1 and Dpb11 are recruited in a sequential manner, but rather suggests that they associate with origins concomitantly. Therefore, it is conceivable that once the macromolecular complex containing Dpb11, Sld2, Pol $\varepsilon$, and GINS is formed at the G1-S-phase boundary, this complex associates with origins. Because the formation of the complex between Dpb11 and Sld2 is required for the initiation of DNA replication and is regulated positively by S-Cdk activity (Masumoto et al. 2002), the formation of the macromolecular complex may be regulated by S-Cdk through Sld2 phosphorylation. In Xenopus egg extracts, Cut5, the counterpart of Dpb11, associates with chromatin without GINS (Kubota et al. 2003). This apparent discrepancy is presumably attributable to the detection procedures for chromatin binding: the ChIP assay in yeast and chromatin fractionation in Xenopus extracts. A possible explanation that reconciles these data is that Dpb11/Cut5 associates with chromatin in the absence of GINS, whereas it requires GINS to associate with replication origins.

A
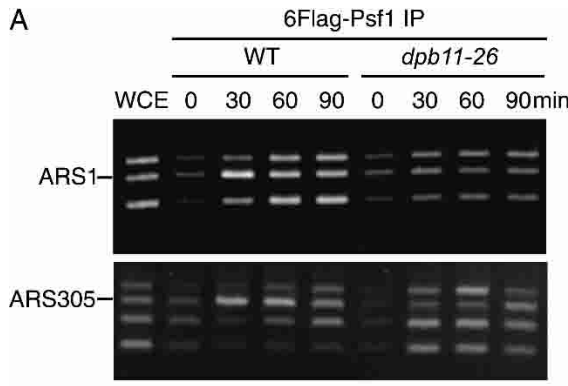

B

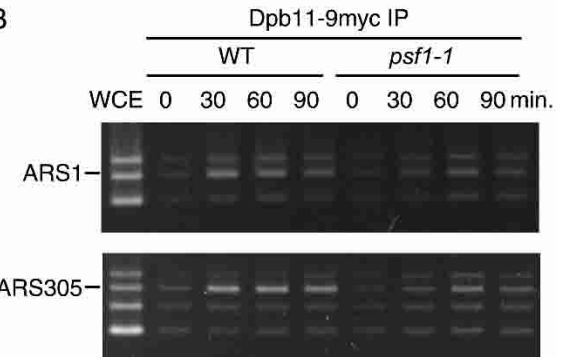

Figure 7. Associations of Psf 1 and Dpb11 with origins are mutually dependent. (A) Association of Psf1 with origins requires Dpb11. YYT2 (6Flag-Psf1; WT) and YYK42 (6Flag-Psf1; dpb1126) cells were arrested in G1 phase by $\alpha$-factor at $23^{\circ} \mathrm{C}$ for $3 \mathrm{~h}$ and released in YPAR containing $0.15 \mathrm{M} \mathrm{HU}$ at $33^{\circ} \mathrm{C}$. Cells were withdrawn from the culture every $30 \mathrm{~min}$. 6Flag-Psfl was immunoprecipitated from each extract with an anti-Flag antibody. (B) Association of Dpb11 with origins requires Psf1. YHM011 (Dpb11-9myc; WT) and YYK43 (Dpb11-9myc; psf1-1) cells were arrested in $\mathrm{G} 1$ phase with $\alpha$-factor at $23^{\circ} \mathrm{C}$ for $3 \mathrm{~h}$ and released in YPAR containing $0.15 \mathrm{M} \mathrm{HU}$ at $34^{\circ} \mathrm{C}$. Cells were withdrawn from the culture every $30 \mathrm{~min}$. PCR was performed on immunoprecipitates derived from the same number of cells at each time point. 
Proteins associated with DNA replication forks

ChIP assays have shown that Mcm, Cdc45, Sld3, and Pol $\varepsilon$ associate first with origins and then with their neighboring fragments (Aparicio et al. 1997; Masumoto et al. 2000; Kamimura et al. 2001). These observations suggest that these proteins move from origins to neighboring regions together with replication fork progress. They further suggest that these proteins participate in the elongation step of DNA replication. It is consistent that, under nonpermissive conditions after release from HU block that stalls replication forks, mutations in these proteins result in defective DNA replication. In the present study, we also observed that Psf1 associates with both the ARS fragment and with fragments surrounding the ARS [Figs. 5, 7A (WT)].

In contrast with the observation described above, psf1-1 cells completed DNA synthesis and entered the subsequent phase of the cell cycle after release from $\mathrm{HU}$ block at the restrictive temperature, although $S$ phase progressed very slowly. This phenomenon might be explained in two ways. Firstly, psf1-1 cells are defective in late-origin firing, and the consequent reduced number of replication forks caused the slow progression of S phase. Secondly, the elongation step may be partially defective in psf1-1 cells. We cannot yet discriminate between these two possibilities. In the case of Mcm and Cdc45, conditional degron mutants revealed their essentiality for the elongation step, whereas point mutations do not give a clear defect (Labib et al. 2000; Tercero et al. 2000). Sld5, Psf1, and Psf2 were recently found to be defective in DNA replication by genome-wide degron screening in which uncharacterized essential ORFs were fused to degrons. Moreover, the degron versions of Sld5 and Psf 2 did not progress through the cell cycle at the restrictive temperature after release from HU block (the Psf1-degron is not tight enough to use in this experiment; M. Kanemaki, A. Sanchez-Diaz, and K. Labib, pers. comm.). Therefore, the psf1-1 mutation may not be appropriate for the analysis of Psf1 function in the elongation step of chromosomal DNA replication, and it is likely that GINS also functions in the step(s) other than the initiation of DNA replication.

GINS requires Dpb11 for its association with origins. However, although it associates with origins, Dpb11 does not move with replication forks but dissociates from origins soon after its function. Therefore, the interaction between Dpb11 and GINS must be transient and limited to the assembly process. This is consistent with our failure to coimmunoprecipitate Dpb11 with Psf1 or Pol $\varepsilon$. It should be noted that the Dpb11-Pol $\varepsilon$ complex is only detected using cross-linking reagent.

GINS purified from Xenopus egg extract showed a ring-like structure under electron microscope (Kubota et al. 2003). The ring-like shape of GINS may allow it to encircle the DNA as a clamp for the replication proteins during the elongation step of DNA replication, like a PCNA clamp. Considering the strong genetic interactions between Pol $\varepsilon$ and Dpb11, and between Dpb11, Sld5, and Psf1, GINS may work as the clamp for Pol $\varepsilon$.
From the interactions between the genes encoding these components (Fig. 2C), we may predict the arrangement of these components in GINS. Because sld5-12 is suppressed by high-copy PSF1 and PSF2 but not by PSF3, and because psf1-1 is suppressed by SLD5 and PSF3 but not by PSF2, Sld5 seems to be sandwiched between Psf1 and Psf2, and Psf1 between Psf3 and Sld5. Therefore, we propose that they are arranged Psf2:Sld5:Psf1:Psf3. Consistent with this, a genome-wide two-hybrid analysis using Sld5 as bait also identified Psf1 and Psf2 but not Psf3 (Uetz et al. 2000; Ito et al. 2001). Furthermore, Psf1 coimmunoprecipitated with Sld5 and Psf2 but not with Psf3 under stringent conditions (Y. Kamimura and $\mathrm{H}$. Araki, unpubl.).

Sld5 interacts weakly with Pol $\delta$, because the deletion of Pol 32, a nonessential subunit of Pol $\delta$, enhances the growth defect of sld5-12 (Ohya et al. 2002). This raises the possibility that GINS also functions for Pol $\delta$ as well as Pol $\varepsilon$. In Escherichia coli, the $\tau$ subunit of the replicative DNA polymerase, Pol III, connects two polymerases at the replication fork to coordinate leading- and lagging-strand synthesis (Kim et al. 1996). To date, no counterpart of the $\tau$ subunit has been found in eukaryotic cells. Because Sld5 interacts with two replicative polymerases, GINS may coordinate leading- and laggingstrand synthesis, like the $\tau$ subunit of Pol III.

\section{Conservation of replication proteins in eukaryotes}

Many replication proteins are conserved from yeast to human cells. This suggests that the replication mechanism of eukaryotes is well conserved. However, candidate homologs of Dpb11, Sld2, and Sld3 have not yet been identified in higher eukaryotes, whereas fission yeast has counterparts to all these proteins. Therefore, the amino acid sequences of these proteins may have diversified from yeast to higher eukaryotes. TopBP1 in human cells and Mus101 in Drosophila contain eight and seven BRCT repeats, respectively, and are thought to be functional homologs of Dpb11 because they are involved in DNA replication and repair (Yamamoto et al. 2000; Mäkiniemi et al. 2001). Therefore, we expect that the other two proteins, Sld2 and Sld3, have also diversified during the evolution from yeasts to higher eukaryotes and that their functional homologs will soon be found.

The diversity of these proteins probably reflects the regulatory mechanisms of DNA replication. For example, micro-organisms, including yeasts but not higher eukaryotes, are very sensitive to nutrient conditions in culture media, and regulate their cell cycle and consequently their DNA replication by responding to nutrient levels. In this context, these proteins act closely with the regulatory machinery of the cell cycle. In fact, the interaction between Dpb11 and Sld2 is regulated by the phosphorylation of Sld2 by Cdk (Masumoto et al. 2002). Moreover, Schizosaccharomyces pombe Sld3 (SpSld3) is also hyperphosphorylated in G2/M phase and hypophosphorylated in $S$ phase, although the meaning of this phosphorylation has not been elucidated (Nakajima and 
Masukata 2002). In contrast with these proteins, highly conserved proteins may work as the replication machinery itself. The proteins reported here are also highly conserved. We therefore anticipate that GINS works as one of the components of highly conserved replication machinery, for example, together with the DNA polymerases. Future biochemical studies will clarify this point.

\section{Materials and Methods}

\section{Micro-organisms}

Yeast strains used in this study are listed in Supplementary Table 1. E. coli DH5 $\alpha$ and BL21(DE3) were used for plasmid propagation and recombinant protein production, respectively.

\section{Plasmid construction}

YCp22-SLD5 and YEp195-SLD5 were constructed by subcloning the 1.8-kb NheI-NdeI SLD5 DNA fragment into the XbaISmaI sites of YCplac22 and YEplac195 (Gietz and Sugino 1988), respectively. YCp22-SLD5 was used as a template to engineer an NdeI site at the first methionine codon and an XhoI site after the stop codon by PCR. The PCR product was cloned into the NdeI-Xhol sites of pET15b. YIp211-GST-SLD5 was constructed as follows: first, YCp22-SLD5 was mutagenized by PCR, with the resultant plasmid containing an EcoRI-BamHI site before the first methionine of Sld5. The GST fragment was cloned into the EcoRI-BamHI sites, and the KpnI-HindIII fragment of YCp22-SLD5 was cloned into KpnI-HindIII of the resultant plasmid. This plasmid was digested with $\mathrm{HpaI}$ before transformation into yeast. YCp22-PSF1 and YEp195-PSF1 were constructed by subcloning the 1.6-kb KpnI-EcoRI PSF1 DNA fragment into the KpnI-EcoRI sites of YCplac22 and YEplac195, respectively. pET15b-PSF1 was constructed as follows: YCp22PSF1 was used as a template to engineer an NdeI site at the first methionine codon and an XhoI site after the stop codon by PCR. These PCR products were cloned into the NdeI-XhoI sites of pET15b. YIp211-6FLAG-PSF1 was constructed by stepwise insertion of FLAG and 5FLAG fragments into the translation initiation site and truncation of the C-terminal portion of PSF1 by HpaII cleavage. This plasmid was digested with SnaBI before transformation. To clone the PSF2 gene, YJL072c was amplified by PCR using oligonucleotides 5 '-ACGGTCCTAGCTTCAAA TGTGATATCTTTC-3' and 5' ${ }^{\prime}$-TAACATGTTCAGATATCCA GGAAGTGGC-3'. This PCR product was digested with EcoRV and cloned into the EcoRV site of pBlueScript $\mathrm{KS}^{+}$(pBS-PSF2). YCp22-PSF2 and YEp195-PSF2 were constructed by subcloning the 1.0-kbp PstI-SalI PSF2 fragment into the PstI-SalI sites of YCplac22 and YEplac195, respectively. All of the DNA inserts amplified by PCR were sequenced to confirm that there were no mutations in the PCR products.

\section{Disruption of the SLD5, PSF1, PSF2, and PSF3 genes}

The NdeI-PvuII SLD5 fragment was cloned into the XbaI-SmaI sites of pBlueScript SK ${ }^{+}$. The SalI-NdeI fragment of SLD5 was replaced with the LEU2 fragment isolated from YDp-L (Berben et al. 1991). The resultant plasmid was cleaved with PvuII and used to transform W303-1A/1B cells to disrupt the SLD5 gene.

The StuI-EcoRI PSF1 fragment was subcloned into the EcoRVEcoRI sites of pBlueScript SK ${ }^{+}$. The BgIII fragment of PSF1 was replaced with the LEU2 fragment isolated from YDp-L (Berben et al. 1991). The resultant plasmid was digested with HindIII and PstI, and introduced into W303-1A/1B cells.
$B a m H I$ sites were introduced just upstream and downstream from the PSF2 ORF using PCR. The BamHI fragment of PSF2 was replaced by the LEU2 fragment isolated from YDp-L. The resultant plasmid was digested with PstI and SalI and introduced into W303-1A/1B cells.

To disrupt PSF3, the 600-bp upstream and 700-bp downstream fragments of PSF3 amplified by PCR were cloned into pBlueScript $\mathrm{SK}^{+}$, and the LEU2 fragment was inserted between them. The resultant plasmid was digested with BgIII and introduced into W303-1A/1B cells.

Southern blot analysis was performed on the $\mathrm{Leu}^{+}$transformants to confirm that one copy of the endogenous gene was successfully disrupted.

\section{Isolation of thermosensitive mutants}

SLD5 was amplified using PCR with Taq DNA polymerase, and used to transform YYK35 [sld5s::LEU2 (YEp195-SLD5)] cells with PstI- and SalI-cleaved YCplac22 (Muhlrad et al. 1992). Approximately 7400 transformants grown at $23^{\circ} \mathrm{C}_{\text {on Ura }}{ }^{-} \mathrm{Trp}^{-}$ plates were replica-plated onto two plates containing $0.1 \%$ 5 -fluoroorotic acid (5-FOA). One plate was incubated at $23^{\circ} \mathrm{C}$ and the other at $37^{\circ} \mathrm{C}$. Four clones showed temperature-sensitive growth. Plasmid DNA was recovered from each of them, and the DNA sequence of the SLD5 portion was determined (Fig. 1A). The EcoRI-PstI fragment of the plasmid was cloned into YIplac2 11 and was used to transform the YYK9 (W303-1Ab) strain after digestion with $\mathrm{HpaI}$. $\mathrm{Ura}^{+}$transformants were grown at $23^{\circ} \mathrm{C}$, spread onto 5 -FOA plates, and a temperature-sensitive colony in which URA3 is popped out was selected.

The procedures were the same for PSF1 as those described for SLD5, with slight modification (below). YYK41 [psf1 :: LEU2 (YEp195-PSF1)] was used. Of about 1500 transformants, three clones showed thermosensitive growth. One clone was found to have a single point mutation, and was designated psf1-1. The other two clones had two point mutations, one of which was the same as that occurring in psf1-1; the other was a silent mutation. The KpnI-EcoRI fragment encoding the psf1-1 mutation was cloned into YIplac211 and was used to transform strain YYK9 (W303-1Ab) after digestion with Tth111I. Ura ${ }^{+}$transformants were grown at $23^{\circ} \mathrm{C}$, spread onto 5-FOA plates, and a temperature-sensitive colony was selected in which $U R A 3$ is popped out.

\section{Multicopy suppressor screening}

A YEp24-based genomic library was transformed into sld5-12 and psf1-1 mutants. Cells were incubated at $23^{\circ} \mathrm{C}$ for a day on SD-Ura plates; incubation temperatures were shifted up to $30^{\circ} \mathrm{C}$ for sld5-12 and $34^{\circ} \mathrm{C}$ for psf1-1. Of the sld5-12 cells, 15 transformants grew at $30^{\circ} \mathrm{C}$ from about $20,000 \mathrm{Ura}^{+}$transformants. Plasmid DNA was recovered from each of them, and the DNA sequences were determined. Twelve clones were found to carry SLD5, and the remaining three clones carried PSF1. Of the psf1-1 cells, three transformants grew at $34^{\circ} \mathrm{C}$ from $7680 \mathrm{Ura}^{+}$ transformants. One clone was found to carry PSF1, and the other two clones carried PSF3.

\section{Immunoprecipitation}

Cells $\left(5 \times 10^{9}\right)$ were harvested, washed once with water, and resuspended in $0.8 \mathrm{~mL}$ lysis buffer [50 mM HEPES-KOH at $\mathrm{pH}$ $7.5,300 \mathrm{mM} \mathrm{KCl}, 0.05 \%$ Tween- $20,0.005 \%$ NP-40, $10 \%$ glycerol, $1 \times$ Complete Protease Inhibitor Cocktail (Boehringer Mannheim), 1\% protease inhibitor (Sigma), $2 \mathrm{mM} \beta$-glycerophosphate, $2 \mathrm{mM} \mathrm{NaF}, 0.4 \mathrm{mM} \mathrm{Na}_{3} \mathrm{VO}_{4}, 0.5 \mathrm{mM} \mathrm{Na}$-pyrophos- 
phate] containing $5 \mathrm{mg} / \mathrm{mL}$ bovine serum albumin (BSA). Cells were disrupted with glass beads using a bead beater. Cell lysates were clarified by centrifugation for $20 \mathrm{~min}$ at $4^{\circ} \mathrm{C}$. Protein extracts were adsorbed onto $0.5 \mathrm{~mL}$ (75\% vol/vol slurry) of sepharose 4B Fast Flow (Pharmacia) for $30 \mathrm{~min}$ at $4^{\circ} \mathrm{C}$. The beads were then pelleted, and the supernatant was recovered and mixed with $100 \mu \mathrm{L}$ anti-Flag (M2) beads (Sigma) for $5 \mathrm{~h}$ at $4^{\circ} \mathrm{C}$. The beads were washed three times with lysis buffer containing $0.1 \mathrm{mg} / \mathrm{mL}$ BSA, then washed three times with $1 \mathrm{~mL}$ cold lysis buffer. The immunocomplex was eluted by incubating the beads with lysis buffer containing $100 \mu \mathrm{g} / \mathrm{mL} 3 \times$ Flag peptides (Sigma).

\section{Preparation of antibodies}

Sld5 and Psf1 proteins were expressed in E. coli BL21(DE3) cells and were recovered in the insoluble fraction after disruption of the cells. The proteins were either solubilized (Sld5) or separated on SDS-PAGE (Psf1), and then used to immunize rabbits.

\section{Other methods}

Gel filtration of 6Flag-Psf1 immunoprecipitates was performed using a Superdex 200 column (Amersham Pharmacia Biotech) equilibrated in lysis buffer (described above). The chromatinbinding assay was performed as described (Kamimura et al. 2001), except that spheroplasts were lysed in $0.2 \mathrm{M}$ sorbitol buffer at the final step. Synchronization of yeast cells, N/N 2-D gel analysis, the two-hybrid assay, and ChIP assay were performed as described (Kamimura et al. 1998, 2001).

\section{Acknowledgments}

We thank Y. Kawasaki and S. Tanaka for yeast strains, H. Masukata and $\mathrm{H}$. Takisawa for critical reading of the manuscript, and $\mathrm{H}$. Takisawa and K. Labib for information before publication. This study was partially supported by a Grant-in-Aid from the Ministry of Education, Culture, Sports, Science, and Technology, Japan.

The publication costs of this article were defrayed in part by payment of page charges. This article must therefore be hereby marked "advertisement" in accordance with 18 USC section 1734 solely to indicate this fact.

\section{References}

Aparicio, O.M., Weinstein, D.M., and Bell, S.P. 1997. Components and dynamics of DNA replication complexes in S. cerevisiae: Redistribution of MCM proteins and Cdc45p during S phase. Cell 91: 59-69.

Aparicio, O.M., Stout, A.M., and Bell, S.P. 1999. Differential assembly of Cdc45p and DNA polymerases at early and late origins of DNA replication. Proc. Natl. Acad. Sci. 96: 91309135.

Araki, H., Hamatake, R.K., Morrison, A., Johnson, A.L., Johnston, L.H., and Sugino, A. 1991. Cloning DPB3, the gene encoding the third subunit of DNA polymerase II of Saccharomyces cerevisiae. Nucleic Acids Res. 19: 4867-4872.

Araki, H., Leem, S.-H., Phongdara, A., and Sugino, A. 1995. Dpb11, which interacts with DNA polymerase II $(\varepsilon)$ in Saccharomyces cerevisiae, has a dual role in S-phase progression and at a cell cycle checkpoint. Proc. Natl. Acad. Sci. 92: 11791-11795.

Bell, S.P. and Dutta, A. 2002. DNA replication in eukaryotic cells. Annu. Rev. Biochem. 71: 333-374.
Bell, S.P., Kobayashi, R., and Stillman, B. 1993. Yeast origin recognition complex functions in transcription silencing and DNA replication. Science 262: 1844-1849.

Berben, G., Dumont, J., Gilliquet, V., Bolle, P.-A., and Hilger, F. 1991. The YDp plasmids: A uniform set of vectors bearing versatile gene disruption cassettes for Saccharomyces cerevisiae. Yeast 7: 475-477.

Bork, P., Hoffman, K., Bucher, P., Neuwald, A.F., Altschul, S.F., and Koonin, E.V. 1997. A superfamily of conserved domains in DNA damage-responsive cell cycle checkpoint proteins. FASEB J. 11: 68-76.

Brewer, B.J. and Fangman, W.L. 1987. The localization of replication origins on ARS plasmids in S. cerevisiae. Cell 51: 463-471.

Callebaut, I. and Mornon, J.-P. 1997. From BRCA1 to RAP1: A widespread BRCT module closely associated with DNA repair. FEBS Lett. 400: 25-30.

Campbell, J.L. and Newlon, C.S. 1991. Chromosomal DNA replication, In The molecular and cellular biology of the yeast Saccharomyces: Genome dynamics, protein synthesis, and energetics (eds. J.R. Broach, J.R. Pringle, and E.W. Jones), pp. 41-146. Cold Spring Harbor Laboratory Press, Cold Spring Harbor, NY.

Dardalhon, M., M.-Schwencke, N., and Averbeck, D. 2000. Disruption and functional analysis of six ORFs on chromosome IV: YDR013w, YDR014w, YDR015c, YDR018c, YDR020c, YDR021w (FAL1). Yeast 16: 267-276.

Ferguson, B.M., Brewer, B.J., Reynolds, A.E., and Fangman, W.L. 1991. A yeast origin of replication is activated late in $S$ phase. Cell 65: 507-515.

Gietz, R.D. and Sugino, A. 1988. New yeast-Escherichia coli shuttle vectors constructed with in vitro mutagenized yeast genes lacking six base-pair restriction sites. Gene 74: 527534.

Hopwood, B. and Dalton, S. 1996. Cdc45p assembles into a complex with Cdc46p/Mcm5p, is required for minichromosome maintenance, and is essential for chromosomal DNA replication. Proc. Natl. Acad. Sci. 93: 12309-12314.

Ito, T., Chiba, T., Ozawa, R., Yoshida, M., Hattori, M., and Sakaki, Y. 2001. A comprehensive two-hybrid analysis to explore the yeast protein interactome. Proc. Natl. Acad. Sci. 98: 4569-4574.

Kamimura, Y., Masumoto, H., Sugino, A., and Araki, H. 1998. Sld2, which interacts with Dpb11 in Saccharomyces cerevisiae, is required for chromosomal DNA replication. Mol. Cell. Biol. 18: 6102-6109.

Kamimura, Y., Tak, Y-S., Sugino, A., and Araki., H. 2001. Sld3, which interacts with Cdc45 (sld4), functions for chromosomal DNA replication in Saccharomyces cerevisiae. EMBO J. 20: 2097-2107.

Kim, S., Dallmann, H.G., McHenry, C.S., and Marians, K.J. 1996. Tau couples the leading- and lagging-strand polymerases at the Escherichia coli DNA replication fork. J. Biol. Chem. 271: 21406-21412.

Kubota, Y., Takase, Y., Komori, Y., Hashimoto, Y., Arata, T., Kamimura, Y., Araki, H., and Takisawa, H. 2003. A novel ring-like complex of Xenopus proteins essential for the initiation of DNA replication. Genes \& Dev. (this issue).

Labib, K., Tercero, J.A., and Diffley, J.F.X. 2000. Uninterrupted $\mathrm{Mcm}$ 2-7 function required for DNA replication fork progression. Science 288: 1643-1647.

Mäkiniemi, M., Hillukkala, T., Tuusa, J., Reini, K., Vaara, M., Huang, D., Pospiech, H., Majuli, I., Westerling, T., Mäkelä, T.P., et al. 2001. BRCT domain-containing protein TopBP1 functions in DNA replication and damage response. J. Biol. Chem. 276: 30399-30406. 
Masumoto, H., Sugino, A., and Araki, H. 2000. Dpb11 controls the association between DNA polymerase $\alpha$ and $\varepsilon$ and the autonomously replicating sequence region of budding yeast. Mol. Cell. Biol. 20: 2809-2817.

Masumoto, H., Muramatsu, S., Kamimura, Y., and Araki, H. 2002. S-Cdk-dependent phosphorylation of Sld2 essential for chromosome DNA replication in budding yeast. Nature 415: 651-655.

Muhlrad, D., Hunter, R., and Parker, R. 1992. A rapid method for localized mutagenesis of yeast genes. Yeast 8: 79-82.

Nakajima, R. and Masukata, H. 2002. SpSld3 is required for loading and maintenance of SpCdc45 on chromatin in DNA replication in fission yeast. Mol. Biol. Cell 13: 1462-1472.

Nishitani, H. and Lygerou, Z. 2002. Control of DNA replication licensing in a cell cycle. Genes Cells 7: 523-534.

Ohya, T., Kawasaki, Y., Hiraga, S., Kanbara, S., Nakajo, K., Nakashima, N., Suzuki, A., and Sugino, A. 2002. The DNA polymerase domain of pol $\varepsilon$ is required for rapid, efficient, and highly accurate chromosomal DNA replication, telomere length maintenance, and normal cell senescence in Saccharomyces cerevisiae. J. Biol. Chem. 277: 28099-28108.

Stern, D.F., Zheng, P., Beidler, D.R., and Zerillo, C. 1991. Spk1, a new kinase from Saccharomyces cerevisiae, phosphorylates proteins on serine, threonine, and tyrosine. Mol. Cell. Biol. 11: 987-1001.

Strahl-Bolsinger, S., Hecht, A., Luo, K., and Grunstein, M. 1997. SIR2 and SIR4 interactions differ in core and extended telomeric heterochromatin in yeast. Genes \& Dev. 11: 83-93.

Tanaka, T. and Nasmyth, K. 1998. Association of RPA with chromosomal replication origins requires an $\mathrm{Mcm}$ protein, and is regulated by Rad53, and cyclin- and Dbf4-dependent kinases. EMBO J. 17: 5182-5191.

Tanaka, T., Knapp, D., and Nasmyth, K. 1997. Loading of an $\mathrm{Mcm}$ protein onto DNA replication origins is regulated by Cdc6p and CDKs. Cell 90: 649-660.

Tercero, J.A., Labib, K., and Diffley, J.F.X. 2000. DNA synthesis at individual replication forks requires the essential initiation factor Cdc45. EMBO J. 19: 2082-2093.

Uetz, P., Giot, L., Cagney, G., Mansfield, T.A., Judson, R.S., Knight, J.R., Lockshon, D., Narayan, V., Srinivasan, M., Pochart, P., et al. 2000. A comprehensive analysis of proteinprotein interactions in Saccharomyces cerevisiae. Nature 403: 623-627.

Winzeler, E.A., Shoemaker, D.D., Astromoff, A., Liang, H., Anderson, K., Andre, B., Bangham, R., Benito, R., Boeke, J.D., Bussey, H., et al. 1999. Functional characterization of the $S$. cerevisiae genome by gene deletion and parallel analysis. Science 285: 901-906.

Yamamoto, R.R., Axton, J.M., Yamamoto, Y., Saunders, R.D.C., Glover, D.M., and Henderson, D.S. 2000. The Drosophila mus101 gene, which links DNA repair, replication and condensation of heterochromatin in mitosis, encoded a protein with seven BRCA1 C terminus domains. Genetics 156: 711-721.

Zhang, X., Moréra, S., Bates, P.A., Whitehead, P.C., Coffer, A.I., Hainbucher, K., Nash, R.A., Sternberg, M.J.E., Lindhal, T., and Freemout, P.S. 1998. Structure of an XRCC1 BRCT domain: A new protein-protein interaction module. EMBO $J$. 17: 6404-6411.

Zou, L. and Stillman, B. 2000. Assembly of a complex containing $\mathrm{Cdc} 45 \mathrm{p}$, replication protein $\mathrm{A}$ and $\mathrm{Mcm} 2$ at replication origins controlled by S-phase cyclin dependent kinases and Cdc7p-Dbf4p kinase. Mol. Cell. Biol. 20: 3086-3096.

Zou, L., Mitchell, J., and Stillman, B. 1997. CDC45, a novel yeast gene that functions with the origin recognition complex and proteins in initiation of DNA replication. Mol. Cell. Biol. 17: 553-563. 


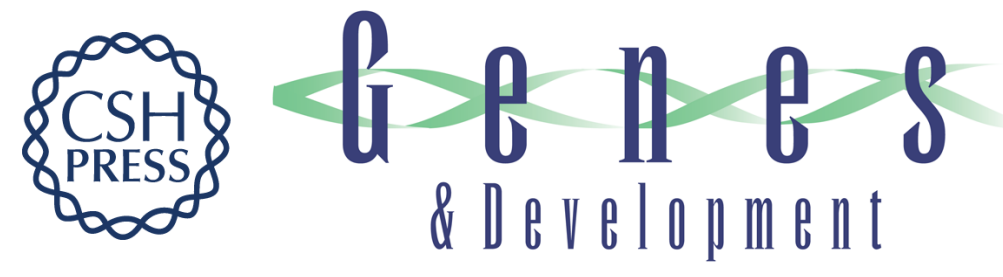

\section{GINS, a novel multiprotein complex required for chromosomal DNA replication in budding yeast}

Yuko Takayama, Yoichiro Kamimura, Mariko Okawa, et al.

Genes Dev. 2003, 17:

Access the most recent version at doi:10.1101/gad.1065903

Supplemental http://genesdev.cshlp.org/content/suppl/2003/05/04/17.9.1153.DC1
Material

References This article cites 36 articles, 22 of which can be accessed free at: http://genesdev.cshlp.org/content/17/9/1153.full.html\#ref-list-1

License

Email Alerting

Receive free email alerts when new articles cite this article - sign up in the box at the top Service right corner of the article or click here.

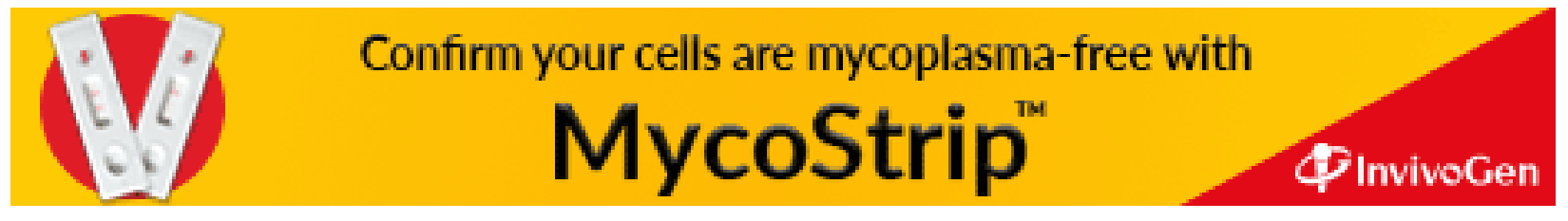

